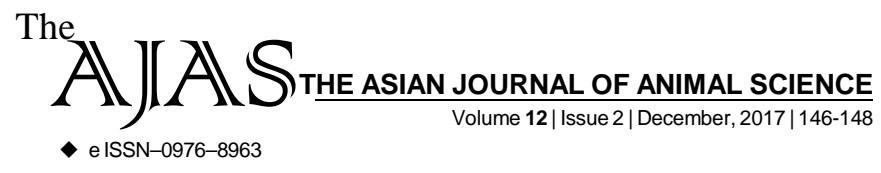

DOI : 10.15740/HAS/TAJAS/12.2/146-148

Visit us | www researchjournal.co in " $\mathrm{S}$.

RESEARCH ARTICLE........

\title{
Development of fried masala shrimp (Solenocera crassicornis) and its economic analysis
}

DEEPA D. MADATHIL, JITESH B. SOLANKI AND SUSHRI SUBHASINI BEHERA

Author for Corresponding -

\section{DEEPA D. MADATHIL}

Department of Fish Processing Technology, College of Fisheries Science, Junagadh Agricultural University, VERAVAL (GUJARAT) INDIA

Email : deepamadathil.d@ gmail.com

See end of the article for Coopted authors'
ABSTRACT...... Large quantities of tiny shrimps are discarded at sea because it is uneconomic to preserve and bring them ashore for marketing. But it offers an opportunity to add value and make this precious resource a valuable product of high acceptability in the market. Red tiny (Solenocera crassicornis) is one of such important fishery resource in Veraval coast which require attention. It is highly rich in protein, fat and minerals. Attempt was made to use this nutritional material for developing ready to eat fried masala shrimp as snack foods. Recipe and ingredients were standardized. Composition and economic value of the product were analyzed.

KEY WORDS...... Solenocera crassicornis, Masala fry shrimp, Economic evaluation

HOW TO CITE THIS ARTICLE - Madathil, Deepa D., Solanki, Jitesh B. and Behera, Sushri Subhasini (2017). Development of fried masala shrimp (Solenocera crassicornis) and its economic analysis. Asian J. Animal Sci., 12(2): 146-148. DOI : 10.15740/HAS/TAJAS/12.2/146-148.

ARTICLE CHRONICLE - Received : 05.10.2017; Revised : 11.11.2017; Accepted : 24.11.2017 